\title{
Д.Л. Шереметьева
}

\section{ПРОФЕССОР БЕЗ ОБРАЗОВАНИЯ: СОЦИАЛЬНЫЕ ЛИФТЫ РОССИЙСКОГО СОЦИУМА ПЕРВОЙ ПОЛОВИНЫ ХХ В. В КАРЬЕРЕ Д.И. РОЗЕНБЕРГА}

\author{
Исследование выполнено при финансовой поддержке гранта Российского научного фонда (проект № 14-18-01725).

\begin{abstract}
Статья посвящена жизненному пути Д.И. Розенберга, который после неудач на политическом поприще сделал стремительную карьеру в системе образования и науки, став признанным знатоком марксизма, профессором, членом-корреспондентом Академии наук СССР. На основе широкого круга источников показаны основные факторы и направления социальных передвижений Розенберга в условиях самодержавия, революции, контрреволюции и советской власти. Прослежены изменения в функционировании таких социальных лифтов, как политические партии и система образования в эпоху войн, революций и радикальных трансформаций в России первой половины XX в.
\end{abstract} \\ Ключевые слова: Д.И. Розенберг; социальный лифт; социальная мобильность; политические партии; система образования.
}

В первой трети XX в. в России в условиях войн, революций и радикальных трансформаций государство безжалостно перекраивало общество, ломало старые социальные границы и лифты и создавало новые. Шансы людей на стремительный подъем по социальной лестнице и опасность падения многократно увеличивались. Преуспеть в жизни и при этом дожить до старости удалось немногим. Среди них Давид Иохелевич Розенберг, родившийся в 1879 г. в нищей многодетной семье в еврейском местечке на западе Российской империи и ставший крупным советским политэкономистом, профессором, членомкорреспондентом Академии наук СССР. Успешная индивидуальная мобильность в революционную эпоху представляет особый интерес, является призмой, позволяющей проследить изменения в механизмах социальных перемещений и понять, как складывались высшие этажи новой социальной иерархии.

В одной из первых специальных статей о Розенберге, опубликованной во втором издании «Большой советской энциклопедии», описан жизненный путь якобы безукоризненного коммуниста и выдающегося ученого. С тех пор этот образ транслируется в изданиях энциклопедического характера [1. С. 394; 2, 3 и др.]. Однако существуют основания для его корректировки. Отдельные сведения, свидетельствующие о неоднозначном, зигзагообразном жизненном пути Розенберга, были приведены исследователями, изучавшими еврейскую диаспору [4, 5 и др.] и Гражданскую войну в Сибири [6. С. 146, 189-190]. При этом основные факторы и направления социальных передвижений Давида Иохелевича в условиях самодержавия, революции, контрреволюции и советской власти не ясны.

Социальное происхождение, или так называемый приписанный социальный статус, имеет принципиальное значение в жизни человека. Согласно наблюдениям социологов, пол, национальность и социальный статус семьи определяют положение индивида в обще- стве, задают координаты его движения по общественной лестнице.

В анкетах Розенберг про себя фиксировал - «мужчина», «еврей», «безотцовщина» [7. Л. 2]. Принадлежность к мужскому полу предполагала ориентацию на высокую общественную активность и социальную мобильность. Однако родиться в еврейской семье на западе Российской империи означало быть ограниченным в правах на собственность, образование, выбор профессии, жить в черте оседлости в местечках с низким уровнем благосостояния, постоянно сталкиваться с проявлениями антисемитизма.

Законодательно обусловленное положение «человека второго сорта» усугублялось низким социальным статусом семьи Розенберга. В жизнеописании, составленном в 1935 г., Давид Иохелевич единственный раз относительно подробно описал своих родителей: «Отец определенной профессии не имел, а занятия менял от случая к случаю, - жил случайными заработками. Мать долгие годы работала в качестве поденщицы, служила домашней работницей» [Там же. Л. 4]. Интересно, что, будучи к тому времени признанным знатоком марксизма, Розенберг не использовал классовую терминологию и сообщал о занятиях отца туманно, вероятно, скрывая прошлое семьи.

Шанс вырваться из неблагополучной социальной среды Розенбергу давала система еврейского религиозного образования. Многовековая традиция всеобщей грамотности и собственная система религиозного образования у евреев обеспечивали относительно высокий интеллектуальный потенциал. Розенберг успешно учился в хедере за счет благотворительности, затем поступил в ешибот для подготовки к званию раввина.

Однако в 1899 г., в возрасте 20 лет, Розенберг радикально поменял образ жизни. Он уехал в Одессу, один из крупнейших городов Российской империи, начал изучать русский язык и готовился к экзамену на «аттестат зрелости». Горизонтальная мобильность и попытка ассимилироваться в огромном русскоговоря- 
щем социуме открывали новые жизненные перспективы. При этом социальное положение оставалось низким, зарабатывать приходилось частными уроками.

Тяжелые условия жизни, волна революционных настроений и эгалитарная социал-демократическая идеология подтолкнули Розенберга к политике. В 1904 г. он примкнул к рабочему движению, вступил во Всеобщий еврейский рабочий союз в Литве, Польше и России (Бунд) и во время Первой русской революции «усиленно изучал марксистскую литературу» [7. Л. 4]. Выбор парии был осмысленным и логичным, так как именно Бунд предлагал программу решения социальных и национальных проблем беднейшего еврейства. К тому времени партия сложилась как социальный институт, имевший внутреннюю иерархию и влиявший на отношения власти-подчинения среди революционеров.

После революции Розенберг пытался продолжить образование. Ему удалось экстерном сдать экзамены и получить диплом о среднем образовании. Он даже намеревался учиться на юридическом факультете [Там же]. Но пройти сквозь фильтр системы образования ему не удалось. Вместо этого в свои 30 лет Розенберг стал активистом рабочего движения, маргиналом без определенной профессии и постоянного места жительства. Последовали аресты и в 1914 г. ссылка в Нарымский край.

В сибирской ссылке Розенберг жил до конца 1916 г., пока затянувшаяся мировая война не вынудила правительство Российской империи призывать в армию политически неблагонадежных. В январе 1917 г. в числе прочих политических ссыльных Розенберг был мобилизован в армию и зачислен в 18-й запасной полк Томского гарнизона. Однако армия изменила социальный статус Розенберга лишь формально. Казарма вскоре стала для него очередной трибуной для политической пропаганды.

Февральская революция положила начало слому социальной системы Российской империи, стала точкой бифуркации для всего российского общества. Розенберг, как и многие другие оппозиционеры, революционеры, подпольщики, представители дискриминируемых ранее национальных меньшинств, получил шанс поднять свой социальный статус и даже попасть в новую политическую элиту.

Весной 1917 г. были парализованы административные органы власти и обозначились новые центры притяжения общественно-политических сил - комитеты общественного порядка и безопасности, советы депутатов, политические партии и народные собрания. Их роль и место во властной иерархии не были закреплены, структуры, функции, полномочия и направления деятельности менялись.

Политическую карьеру в условиях революции Розенберг начал с того, что было лично ему наиболее близко и понятно. В марте 1917 г. он принял участие в учреждении Томской организации Бунда, создании при ней партийного клуба и библиотеки. «Это было на третий день по получении известий о перевороте. В небольшой уютной комнате собрались шесть человек, все старые знакомые $<\ldots>$ спаянные крепкими узами товарищества. Они уже были бундовцами $<\ldots>$ но не было организованной бундовской работы» [8. 1917. № 1. С. 3-4]. Бунд оказался новинкой для Томска. Активисты еврейской социал-демократии были «пришлыми», из политических ссыльных и высланных, и занимали скромные позиции в обществе. Это были солдат Д.И. Розенберг, конторщик И.Л. Магун, учительница Е.С. Лапицкая и др. Социальную базу местной организации Бунда составляли рабочие и ремесленники из беженцев.

В Томске Розенберг успешно выступал на митингах, читал популярные лекции [5. С. 30] и явно выделялся как яркий агитатор и пропагандист, подкованный в марксизме. Его личные политические успехи превосходили достижения еврейского социалдемократического движения в Томске. Численность местных бундистов достигла своего максимума в мае 1917 г., составив всего 55 членов организации и около 40 членов клуба [Там же. С. 27-28]. Летом интерес к Бунду пошел на спад, самостоятельное общественнополитическое значение организация имела лишь в качестве оппозиции сионизму внутри местного еврейского сообщества.

Вполне естественно, что Розенберг стремился расширить сферу деятельности. Весной 1917 г. он принял участие в работе Томского совета солдатских депутатов. Одно из первых политически значимых выступлений Розенберга состоялось в конце апреля 1917 г. на совместном заседании совета солдатских депутатов и совета рабочих депутатов. По вопросам об отношении к Временному правительству, войне и «Займу свободы» Розенберг с оборонческих позиций оппонировал основному докладчику большевику И.Н. Смирнову. Итогом дискуссии стала компромиссная резолюция с выражением условной поддержки Временному правительству [9. 1917. 4 мая].

В мае 1917 г. Розенберг был избран в исполнительный комитет Совета солдатских депутатов Томского гарнизона [Там же. 14 мая] и стал журналистом газеты «Известия Совета солдатских депутатов Томского гарнизона». Тогда же он был избран в комитет Томской организации РСДРП, в котором до осени 1917 г. сосуществовали большевики и меньшевики, и взял на себя ответственность за «пропагандистско-агитаторскую работу» [10. 1917. 3 июня].

Летом - осенью 1917 г. основным занятием Розенберга стала политическая публицистика. В июне октябре 1917 г. он был сотрудником крупной сибирской социал-демократической газеты, органа Томского совета солдатских и рабочих депутатов «Знамя революции». Более того, на первой сибирской конференции Бунда, прошедшей в августе 1917 г. в Иркутске, была поддержана его инициатива по учреждению 
журнала «Сибирский вестник Бунда» [10. 1917. 12 авг.]. К осени Розенбергу удалось наладить выпуск журнала.

Розенберг не имел опыта писательской работы, но стал выдавать сразу большое количество текстов. Под незамысловатыми подписями «Роз», «Розенберг», «Розенберг Д.», свидетельствовавшими об открытости автора, почти в каждом номере «Знамени революции» и «Сибирского вестника Бунда» публиковались произведения Давида Иохелевича.

Он был представителем той революционной волны журналистов, которых профессиональный литератор, этнограф, путешественник, либерал А.В. Адрианов считал безграмотными дилетантами, заполонившими провинциальную прессу [11. С. 17]. Конкретно Розенберга А.В. Адрианов высмеивал как «не владеющего русской речью» [12. 1918. 11 авг.]. Розенберг, действительно, уступал корифею сибирской журналистики по уровню образования и владения русским литературным языком. В статьях большое количество ошибок, опечаток, газетных штампов, нередко встречаются такие фразы: «в стране разложение всякой власти пошло сильными шагами вперед» [10. 1917. 20 июня], «солидный кадр опытных работников» [Там же. 27 авг.] и др. Розенберг постоянно пояснял используемые им в статьях расхожие слова и выражения, обнажая пробелы в собственном образовании и трудности в написании текстов. При этом Розенберг умело пользовался политическими аргументами и делал выводы, логично вытекавшие из текста.

Выступления в прессе, на митингах и собраниях обеспечили Розенбергу известность в Сибири. Ему, по-видимому, удалось зарекомендовать себя в качестве профессионального революционера и убежденного социал-демократа. Это было одним из важнейших составляющих успешной политической карьеры в условиях революции и способствовало повышению политического статуса.

В конце сентября 1917 г. Розенберг участвовал в выборах в Томскую городскую думу по списку местной организации РСДРП. Он был кандидатом под номером три, сразу после председателя городского народного собрания Н.С. Васильева и члена городского народного собрания М.Е. Минца [12. 1917. 27 сент.]. На победу в городских выборах меньшевики не рассчитывали и остались довольны, когда в результате упорной борьбы им удалось собрать 1371 (5,8\%) голос и вырвать целых шесть депутатских мандатов у популярных в Томске большевиков, эсеров и кадетов [8. 1917. № 3. С. 6-7].

Розенберг стал депутатом Томской городской думы, но на этом поприще себя не проявил [5. С. 50; 9. 1917. 28 сент., 3-6 окт.; 10. 1917. 17 сен.; 13. 1917. 28 сен.]. Судя по публицистике, лекциям и выступлениям на митингах, собраниях и заседаниях, он претендовал на более высокое положение в политической иерархии, мыслил в масштабах государства, а не отдельного муниципалитета.

Осенью 1917 г. Розенберг сосредоточился на пропаганде идеи Всероссийского Учредительного собрания [10. 1917. 10-25 окт., 10 нояб.] и стал кандидатом в депутаты от РСДРП. В списке партии по Томскому избирательному округу он значился шестым, уступив не только обязательному кандидату от ЦК, приватдоценту Н.А. Рожкову, но и члену исполнительного комитета Томского губернского народного собрания В.П. Денисову, члену Новониколаевского городского народного собрания, редактору газеты «Голос Сибири» Н.А. Гудкову, служащему Кустарного комитета Томской и Алтайской губерний К.И. Замараеву и члену правления Мариинского союза кооперативов И.С. Гвиздону [14. 1917. 29 окт.]. Розенберг был рекомендован избирателям как солдат 18-го полка. Выборы в Учредительное собрание в Томске прошли в ноябре 1917 г., за меньшевиков отдали голоса 1008 (5\%) избирателей [15. С. 213]. С такими результатами партийная организация не получила представительства во всероссийскую конституанту.

В ноябре 1917 г. Розенберг шел по списку Бунда первым кандидатом от Западной Сибири на Всероссийский еврейский съезд. На этот раз в списках были указаны все его реальные политические статусы - председатель Томской организации Бунда, гласный Томской городской думы, редактор «Сибирского вестника Бунда» [8. 1917. № 6; 10. 1917. 21 нояб.]. В январе 1918 г. на выборах в Западной Сибири Бунд набрал 629 (13\%) голосов и не получил ни одного мандата [5. С. 86].

Розенберг не прошел ни в одно представительное собрание всероссийского уровня. Партийная принадлежность «бундовец и меньшевик» не сулила стремительной политической карьеры в крестьянской Сибири. Однако представления социал-демократов о развитии общества, государства и революционного процесса в России все же подпитывали надежду на близкий политический реванш.

После Октябрьской революции Розенберг занял компромиссную позицию в отношении устанавливавшейся и укреплявшейся советской власти. В докладе «Переживаемый политический момент» 1 ноября 1917 г. на общем собрании членов Томской организации Бунда он критически высказался о большевиках и одновременно заявил, что бороться против захвата власти советами под руководством большевиков недопустимо. По его мнению, необходимо было «примкнуть к движению», «превратив его в общереволюционно-демократическое» [8. 1917. № 5. С. 11; 10. 1917. 5 нояб.]. Через три дня в газетной статье он призывал к созданию единого революционного демократического фронта против потенциальной угрозы контрреволюции [10. 1917. 4 нояб.].

Однако выдержать такую позицию не удалось. Советская власть строилась вопреки демократическим принципам. Дискриминационно-репрессивная полити- 
ка большевиков сужала возможности легальной политической оппозиции. Атмосфера гонений довлела даже над социал-демократами [16. 1918. 14 апр.]. При этом меньшевики не считали возможным встать на путь вооруженной борьбы с большевиками. Розенберг, в частности, с декабря 1917 г. лишь последовательно критиковал политику советского правительства [5. С. 80-82].

В Иркутске в апреле 1918 г. Розенберг был избран членом Сибирского областного комитета Бунда, но следов его деятельности в этом качестве пока не обнаружено. В это время он прекратил издание «Сибирского вестника Бунда», обосновывая свое решение «плохой распространяемостью» журнала, «отсутствием в Сибири широких еврейских трудящихся масс», «слабым освещением партийной жизни» и «резким вздорожанием типографского тарифа» [8. 1918. № 5. С. 15]. С тех пор Розенберг перестал писать статьи на столь близкие ему ранее темы борьбы с антисемитизмом и еврейского рабочего движения. Национальность все меньше определяла его жизненный выбор.

В условиях разгоравшейся Гражданской войны Розенберг тесно связал свою деятельность с меньшевиками. Бюро Сибирского объединения организаций РСДРП 10 апреля 1918 г. приступило к выпуску общественно-литературной газеты «Заря» под редакцией А.А. Богданова, Д.И. Розенберга и С.К. Неслуховского. Главной задачей издания была пропаганда «старых заветов революционного марксизма» [16. 1918. 10 апр.]. Основной массив публикаций составляли статьи, освещавшие текущие политические события и теоретические вопросы строительства социализма, а также заметки о жизни рабочих. Розенберг продолжал критиковать политику большевиков, пророча скорое падение их власти [Там же. 17. 21 апр.].

Антибольшевистский переворот в конце мая - августе 1918 г. в очередной раз изменил «политический ландшафт» в Сибири. Меньшевики практически не принимали участия в свержении советской власти, и с переходом высшей власти на освобожденной от большевиков территории к Временному Сибирскому правительству положение Розенберга принципиально не изменилось. Он с оговорками поддержал переворот и условно признал Временное Сибирское правительство, но, опасаясь восстановления «позорных старых порядков» [Там же. 22 июля], вскоре оказался в привычной ему роли оппозиционера.

Основным инструментом политической борьбы для Розенберга оставалась пресса. До октября 1918 г. он был бессменным членом редколлегии и автором в меньшевистской газете «Заря». С 21 июня 1918 г. до 31 марта 1919 г. Давид Иохелевич возглавлял орган Томской губернской земской управы «Народная газета». К тому же с 1 июля 1918 г. Розенберг сотрудничал в еженедельной газете профессионального союза служащих, мастеровых и рабочих Томской железной дороги «Железнодорожник».
В июле 1918 г. на заседании Частного совещания членов Сибирской областной думы был рассмотрен мандат Розенберга, выданный Западно-Сибирским областным комитетом Бунда. Однако «партии в областной думе специального представительства не имели», поэтому самого Розенберга на заседания не допустили [6. С. 146]. На второй сессии Сибирской областной думы 10 сентября 1918 г. мандат рассматривался комиссией по проверке полномочий депутатов и снова был отклонен [5. С. 110]. Розенбергу в очередной раз не удалось попасть в представительный орган.

В чрезвычайных условиях Гражданской войны политический режим контрреволюции быстро эволюционировал от первоначально декларированного народоправства к авторитаризму. Во все сферы жизни общества проникало влияние военных, укреплялась административная властная вертикаль. Уже осенью 1918 г. в Сибири наглядно проявилась тенденция к ограничению гражданских свобод. Эсеров и социалдемократов-меньшевиков постепенно выдавливали из легального политического пространства, основным их «прибежищем» становились органы городского и земского самоуправления.

В октябре 1918 г. было остановлено издание газеты «Заря». Розенберг, в арсенале которого оставалась только «Народная газета», приспосабливался к ограничению свободы слова. В декабре 1918 г. на Томском губернском земском собрании Давид Иохелевич охарактеризовал газету как «беспартийную» [17. 1918. 17 дек.], а в объявлении о подписке на 1919 г. пояснил, что издание, «являясь органом беспартийным, отстаивающим интересы широких народных масс, стоит на страже полного народовластия, защищая областное устройство Сибири и вместе с тем единство и неделимость России», беспристрастно «освещает политическую жизнь страны и стремится внедрить в сознание населения чувства гражданственности, долга перед родиной и порядка» [18. 1919. 3 янв.]. При этом в январе - марте 1919 г. в многочисленных статьях Розенберг по-прежнему отстаивал мысль, что все пути к справедливому обществу ведут к социализму [Там же. 27 фев.], и осторожно критиковал «и советскую, и несоветскую власть» в России за «уничтожение остатков народного хозяйства» [Там же. 9 марта].

Томская губернская земская управа 31 марта 1919 г. приостановила «Народную газету» из-за «трудностей с типографией» [19. Л. 103]. Для Розенберга это означало потерю работы и возможности влиять на общественное мнение и власть. Депутат Томской городской думы - вот единственный политический статус, который ему удалось сохранить и подтвердить на очередных выборах в июле 1919 г. [9. 1919. 19 июля]. При этом в думе он по-прежнему не вел никакой заметной работы.

В декабре 1919 г. в Томске в результате вооруженного антиколчаковского восстания была установлена советская власть. Сорокалетний социал-демократ, 
марксист с опытом партийной и журналистской деятельности снова оказался перед выбором. 19 декабря на общем собрании томской организации меньшевиков Розенберг призывал к отказу от программыминимум и строительству социализма. Собравшиеся приняли решение о всемерной поддержке советской власти как единственной революционной силы, ведущей активную борьбу с реакцией. Однако учрежденный большевиками Томский революционный комитет подверг резкой критике умеренных социалистов и запретил им легальную политическую деятельность. Организация местных меньшевиков распалась. Некоторые из них вступили в ряды РКП(б), другие отошли от активной партийной работы, а часть снова ушла в политическое подполье [20. С. 54-55].

Розенберг пошел по пути активной интеграции в нарождавшийся советский социум. В феврале 1920 г. он вступил в РКП(б). Первая публикация Розенбергакоммуниста появилась в газете «Знамя революции» 1 мая 1920 г. Замаскировавшись псевдонимом «Рид», он подобострастно писал об «истинных социалистах», «искренне борющихся за освобождение пролетариата». Более того, Розенберг перенял идейнополитические установки, фразеологию и двойные стандарты большевиков, отказавшись от исповедуемых им ранее принципов народовластия, плюрализма, свободы выбора и слова: «Ясно теперь, что все так называемые демократические принципы и демократические завоевания имеют ценность постольку, поскольку они дают возможность борющемуся за власть пролетариату шире развернуть свой размах, доставляют ему новые позиции для более удачных и верных обстрелов. При диктатуре же пролетариата за эти принципы цепляется побитая буржуазия» [10. 1920. 1 мая]. С тех пор Розенберг строго следовал политической линии коммунистической партии и стал апологетом советской власти.

С точки зрения социальной мобильности, вступление в РКП(б), взявшую на себя роль основной несущей конструкции советского государства, сулило Розенбергу выгоды. В условиях дефицита кадров бывший меньшевик, полностью подстроившийся к идеологии и политике коммунистической партии, мог стать «строителем советской власти». Тем более что большевики объявили себя защитниками малых наций и широко использовали малообразованные массы российского еврейства в переустройстве страны [21. С. 60].

Вероятно, с согласия председателя Сибирского бюро ЦК РКП(б) и председателя Сибирского революционного комитета И.Н. Смирнова в мае 1920 г. Розенберг был избран в Томский совет рабочих и красноармейских депутатов [11. 1920. 4 мая] и стал членом бюро Томского губернского комитета РКП(б) [22. Л. 1]. В его ведение предполагалось передать вопросы агитации, пропаганды, национальных меньшинств и профсоюзов [Там же. Л. 7]. Однако Розенберг, по сути, не был допущен к власти. В Томске его хорошо знали как бывшего меньшевика. Поэтому в Сиббюро уже в июне 1920 г. поднимался вопрос о переводе Розенберга в Омск [23. Л. 64]. В конце июня 1920 г. Давид Иохелевич уже выбыл из состава губбюро при невыясненных обстоятельствах.

Не позднее августа 1920 г. Розенберг переехал в Омск, хотя формально он был отозван из Томска в распоряжение Сиббюро только в сентябре 1920 г. [24. Л. 31]. В Омске устроиться удалось редактором журнала «Сибирский путь», издававшегося совместно с Сибирским политическим управлением путей сообщения, Сибирским округом путей сообщения, Сибирским районным комитетом профессионального союза железнодорожников и Сибирской комиссией по водному транспорту. Почти на год Розенберг стал «заложником» пропагандистской работы в маломощных сибирских профсоюзах, пережидая там «военный коммунизм».

Новая экономическая политика отчасти «примирила» бывших меньшевиков с советской властью, открыв для них поле деятельности в сфере организации экономической жизни страны. Почувствовав изменение политической конъюнктуры, Розенберг уже в мае 1921 г. попытался перейти на более перспективную должность. 5 мая 1921 г. бывший меньшевик, заведующий экономическим отделом Сибирского революционного комитета И.М. Майский ходатайствовал в Сиббюро ЦК РКП(б) о переводе Розенберга в экономический отдел и назначении в редакционный коллектив экономического журнала «Жизнь красной Сибири». Однако Сиббюро ЦК РКП(б) оставило Розенберга на «профсоюзной работе», разрешив «в порядке совместительства работать в экономическом отделе Сибревкома» [25. Л. 63]. Всего три недели спустя Розенберг выступил с предложением об организации в Сибири еврейской коммунистической секции и сделал доклад о печальном состоянии производственной пропаганды. Сиббюро ЦК РКП(б) отклонило предложение о евсекции, а на доклад о производственной пропаганде последовала вялая неопределенная реакция [Там же. Л. 82]. Политическая карьера Розенберга явно не складывалась.

В июне 1921 г. Сиббюро ЦК РКП(б) «прикрепило» Розенберга «в качестве лектора к Сибпартшколе» [Там же. Л. 99]. С сентября он начал преподавание в созданном для подготовки коммунистов к организационно-партийной и агитационно-пропагандистской работе Рабоче-крестьянскому коммунистическому университету Сибири (КУС). К профессиям Розенберга как журналиста, редактора и пропагандиста добавилась еще одна - преподаватель. Отсутствие диплома о высшем образовании не помешало Розенбергу разработать курс по политической экономии и успешно читать лекции намного менее образованным, чем он, слушателям. Новая работа отвечала способностям, знаниям и интересам Розенберга. Однако система партийного образования в Сибири только 
начинала формироваться, финансировалась по остаточному принципу и не сулила продвижения по социальной лестнице.

«Материальная нужда, а с другой стороны - внутренняя тяга к газетной работе принудили» Розенберга одновременно с преподаванием в университете ввязаться в издание органа Омского губернского комитета РКП(б) и исполкома «Рабочий путь» [26. Л. 128]. В этой газете с сентября 1921 г. Розенберг был членом редколлегии, в апреле - июне 1922 г. работал ответственным редактором, затем до июня 1923 г. писал политико-экономические обзоры. Статьи и заметки он писал клишированно, копируя тематику и стиль центральных партийных и советских изданий.

Летом 1923 г. Розенберг подводил итоги своей преподавательской работы. По результатам первого выпуска слушателей Рабоче-крестьянского коммунистического университета он написал праздничную статью и сделал умеренно позитивный вывод: «Медленно, но неуклонно, КУС становится высшим рассадником коммунистического просвещения в Сибири» [27. 1923. 24 июня]. Слушатели, преимущественно рабочие и крестьяне, ценили Розенберга за «ясный логический подход к каждому вопросу» [26. Л. 129].

Убедившись, что партийно-политическая карьера для него невозможна, а преподавательская работа вполне по силам и пробелы в образовании ей не препятствуют, Розенберг решился добиваться перевода на более выгодное с точки зрения социального статуса и карьерных возможностей место. Перестраивавшаяся система образования требовала новых, лояльных власти кадров и открывала широкие перспективы перед большевиками-марксистами. При этом Розенбергу разумно было покинуть Сибирь, где его хорошо знали и помнили о его меньшевистском прошлом.

В сентябре 1923 г. Розенберг уехал из Омска в Москву [7. Л. 4]. В столицу традиционно рвались самые амбициозные представители всех слоев общества, в особенности интеллектуалы и представители творческих профессий. Именно в Москве концентрировались политическая элита и обслуживавшие ее функционирование социальные институты.

В Москве Розенберг начал работу в 1924 г. с должности преподавателя политической экономии в Академии коммунистического воспитания имени Н.К. Крупской, где готовили преподавателей средних учебных заведений и руководящих работников народного образования. Уже через год, в 1925 г., Давид Иохелевич был назначен председателем кафедры политэкономии, писал учебные пособия для преподавателей и студентов. В 1926 г. он был утвержден в звании профессора политической экономии [28. Л. 1], пополнив формировавшийся слой коммунистической профессуры.

Первая знаковая научная публикация Розенберга появилась в 1929 г. в журнале экономической секции Коммунистической академии «Проблемы экономики» в «Дискуссионном отделе» [29]. В 1929-1933 гг. результатом многолетнего политического и научного освоения трудов К. Маркса стали комментарии Розенберга к трем томам «Капитала». Профессор относительно стройно изложил основы экономической теории К. Маркса, обозначил контекст развития европейской экономической мысли, но не вдавался в критику. «Комментарии...» удачно вписались в политическую конъюнктуру, стали подспорьем для широкого внедрения марксизма в систему высшего образования и науки. «Комментарии...» Розенберга внимательно прочел И.В. Сталин [30]. Впоследствии они трижды переиздавались и были переведены на несколько иностранных языков.

Апология марксизма и защита идейнополитических основ складывавшейся в СССР экономической системы сыграли важнейшую роль в выживании Розенберга, шансы на которое в условиях судебного процесса «Союзного бюро ЦК РСДРП (меньшевиков)» и расправы над бывшими меньшевиками были сомнительными.

Карьерный рост Розенберга в научнообразовательной сфере продолжался. В 1931-1936 гг. Розенберг руководил кафедрой политэкономии в Институте красной профессуры, готовившем идеологов ВКП(б) и преподавателей общественных наук для вузов. Одновременно Розенберг работал старшим научным сотрудником Института экономики Коммунистической академии.

По таким характеристикам, как членство в ВКП(б), уровень образования и трудовой стаж, Розенберг органично вписывался в коллектив сотрудников Комакадемии. В секции теоретической экономики в 1933 г. работали 12 старших научных сотрудников. Все поголовно состояли в партии. Только у пятерых из них было высшее образование, трое учились в аспирантуре. Траектории профессиональной мобильности старших научных сотрудников названной секции были разнообразны, но большинство имели опыт агитационнопропагандистской, организационно-партийной и преподавательской работы. Научной или околонаучной деятельностью из них занимались ранее только четверо, остальные восемь, включая заведующего секцией В.М. Шурыгина, не имели к ней ранее никакого отношения [31]. На этом фоне Розенберг оказался выдающимся ученым и в 1934 г. Президиум Коммунистической академии присвоил Давиду Иохелевичу ученую степень доктора экономических наук.

Новый социальный статус для Розенберга означал и особую заботу правительства. В 1934 г. ему удалось стать подопечным Комиссии содействия ученым при СНК СССР и обзавестись относительными жилищными удобствами - отдельной квартирой в Москве, площадью около 40 кв. м, с электричеством и уборной [28. Л. 3-4].

В 1936 г., после слияния двух экономических институтов, Розенберг устроился в Институте экономики 
Академии наук СССР. К тому же с 1937 г. он был профессором Московского университета. Розенберга как ценного специалиста, укреплявшего идеологические основы режима, миновала волна Большого терроpa. В 1939 г. ему было присвоено звание членакорреспондента АН СССР.

В 1941 г. Розенберг был эвакуирован в Казань, где до 1943 г. работал профессором в местном университете, а также читал популярные лекции по политэкономии социализма. В публичных выступлениях Розенберг профессионально транслировал идейнополитические установки коммунистической партии, пересказывал «Историю ВКП(б). Краткий курс». Советскую власть профессор-коммунист называл «нашей» и отстраненно повествовал о неких бывших буржуазных партиях эсеров и меньшевиков [32. Л. 9].

После войны Розенберг благополучно вернулся в Москву. В 1945-1948 гг. он работал старшим научным сотрудником Института Маркса - Энгельса - Ленина при ЦК ВКП(б) (ИМЭЛ), в 1947-1950 гг. был профессором кафедры истории народного хозяйства и экономических учений в Московском университете.

Однако в 1948-1949 гг. в СССР формировалась новая идеологическая парадигма, соединившая лозунг борьбы с «низкопоклонством» и антисемитизм. Борьба с евреями превращалась в важное орудие государственной политики [33. С. 389]. Над Розенбергом, никогда не скрывавшим свою национальность, сгущались тучи. В 1948 г. он сдал в печать объемную рукопись «История экономического учения Маркса», но при жизни автора она не увидела свет. В том же году он потерял работу в ИМЭЛ. В 1950 г. семидесятилетний «крупнейший знаток теории марксизмаленинизма» не выдержал нового витка борьбы за вы- живание и социальный статус. По свидетельству современников, он умер прямо на лекции, отказало сердце [34. С. 59-60]. Некрологов не было, а его последняя книга опубликована только после смерти И.В. Сталина.

Жизненный путь Розенберга определили национальная государственная политика, системы образования и политические партии. Пока способному еврейскому мальчику из бедной семьи удавалось получать образование, он учился. Но, когда стало очевидным, что этот «лифт» в Российской империи не приведет его к повышению социального положения, Розенберг стал революционером. Партийно-политическая карьера шла трудно и зигзагообразно: бундовец, меньшевик, затем член РКП(б), он так и не получил доступа к власти. Складывавшаяся в годы нэпа система партийного просвещения позволила ему, недоучившемуся в «прошлой жизни», уже в зрелом возрасте начать научно-преподавательскую карьеру. Подчеркнутая преданность коммунистической партии, выбор профессии «пропагандиста от науки» и неординарные способности стали залогом выживания и слагаемыми личного успеха Розенберга в советском обществе. В революционную эпоху гротескный образ кухарки, управляющей государством, воплощался в жизнь. Сыну евреяподенщика удалось выбиться в научную элиту советского общества и попасть в анналы политэкономии марксизма. Социальные фильтры Российской империи по параметрам «национальность», «бедность», «партийность», «отсутствие образования» закрывали Розенбергу почти все возможности улучшить статус в обществе, а революция и политика советской власти в 1920-1930-х гг., напротив, способствовала взлету по социальной лестнице.

\section{ЛИТЕРАТУРА}

1. Энциклопедия Московского университета. Экономический факультет / ред. В.П. Колесова. М., 2004.

2. Слудковская М.А. Розенберг Давид Иохелевич // Московская энциклопедия. Лица Москвы. Диск 3: Н-Р. М., 2011.

3. Розенберг Давид Иохелевич // Сайт Архива PAH. URL: http://isaran.ru/?q=ru/person\&guid=83E1AFD6-5E32-A327-14C7-7E4527329A5D.

4. Нам И.В. Сибирские организации Бунда в Сибири в 1917 году // Вопросы истории общественно-политической жизни Сибири периода Октября и гражданской войны : сб. ст. / отв. ред. И.М. Разгон. Томск, 1982.

5. Нам И.В., Наумова Н.И. Еврейская диаспора в Сибири в условиях смены политических режимов (март 1917 - февраль 1920 гг.). Красноярск, 2003.

6. Сибирский предпарламент: Частные совещания членов Временной Сибирской областной думы (июнь - август 1918 г.) : сб. док. и материалов / сост. и науч. ред. В.И. Шишкин. Новосибирск, 2013.

7. Государственный архив Российской федерации (ГАРФ). Ф. Р-7668. Оп. 1. Д. 2653.

8. Сибирский вестник Бунда (Томск).

9. Известия Совета солдатских депутатов Томского гарнизона.

10. Знамя революции (Томск).

11. Адрианов А.В. Периодическая печать в Сибири. С указателем изданий в 1918 г. Томск, 1919.

12. Сибирская жизнь (Томск).

13. Голос свободы (Томск).

14. Путь народа (Томск).

15. Ларьков Н.С. Начало гражданской войны в Сибири. Армия и борьба за власть. Томск, 1995.

16. Заря (Томск).

17. Голос Сибири (Томск).

18. Народная газета (Томск).

19. Государственный архив Томской области. Ф. Р-1. Оп. 1. Д. 38.

20. Ларьков Н.С. Декабрьские события 1919 г. в Томске // Вестник Томского государственного университета. История. 2011. № 3 (15). С. 4656.

21. Костырченко Г.В. Тайная политика Сталина: власть и антисемитизм. М., 2001.

22. Государственный архив Новосибирской области (ГАНО). Ф. П-1. ОП. 1. Д. 86.

23. ГАНО. Ф. П-1. ОП. 3. Д. 2.

24. ГАНО. Ф. П-1. Оп. 3. Д. 3. 
25. ГАНО. Ф. П-1. Оп. 3. Д. 18.

26. ГАНО. Ф. П-1. ОП. 1. Д. 954.

27. Рабочий путь (Омск).

28. ГАРФ Ф. Р-4737. Оп. 2. Д. 1912

29. Розенберг Д.И. Производительные силы и производственные отношения в марксистской политической экономической науке // Проблемы экономики. 1929. № 7/8. С. 136-142.

30. Российский государственный архив социально-политической истории. Ф. 588. Оп. 3. Д. 301, $302,303$.

31. Архив Российской академии наук (АРАН). Ф. 350. Оп. 3. Д. 136.

32. АРАН. Ф. 644. Оп. 1. Д. 39.

33. Хлевнюк О.В. Сталин. Жизнь одного вождя. М., 2013. С. 389.

34. Галкин Д.С. В тени сталинских высоток. Исповедь архитектора. М., 2015.

Sheremetyeva Darya L. Institute of History of the Siberian branch of Russian academy of science (Novosibirsk, Russia). E-mail: dalas83@yandex.ru

PROFESSOR WITHOUT EDUCATION: SOCIAL LIFTS OF THE RUSSIAN SOCIETY DURING THE FIRST HALF OF THE XX CENTURY IN THE D.I. ROSENBERG'S CAREER.

Keywords: D.I. Rozenberg; social lift; social mobility; political parties; education system.

The aims of this study are to trace a path of a marginal to the elite and to identify factors of social ascent in a particular case of David Rosenberg (1879-1950). The goals can be achieved by studying representative sources - a compendium of personal and office documents, journalistic, educational and scientific literature. Social discrimination against the Jews in the Russian Empire pushed the Jewish youth to political radicalism. Like many others, Rosenberg could not get an education and a prestigious profession. In 1904 he joined the Bund, led the anti-government agitation among workers and in 1914 he was exiled to Siberia. In the years of the Revolution and the Civil War Rosenberg was a Menshevik, the party publicist and editor of political newspapers in Tomsk. In 1920 Rosenberg changed political orientation and joined RCP(b), the Russian Communist Party of the Bolsheviks. He was in the personnel reserve of the Siberian Bureau of the RCP(b). However as a former Menshevik he could not make a political career. During the New Economic Policy (NEP) Rosenberg-communist had a wide range of other possibilities. The transformation of educational system, an acute shortage of staff allowed him, a dropout in the «past life», to begin scientific and teaching career. In the 1920s Rosenberg taught political economy, he became a communist professor and wrote "A commentary on Marx's "Capital"'. It successfully fit into the political situation and helped with a widespread introduction of Marxism into higher education and science. In the 1930s Rosenberg continued successful scientific and teaching career at institutes and universities in Moscow. As a very valuable specialist who strengthened ideological foundations of the regime he escaped the Great Terror. In 1939 Rosenberg was awarded the title of Corresponding Member of the USSR Academy of Sciences. In 1945-1948 he worked as a senior researcher at the Marx-Engels-Lenin (MEL) Institute of the Central Committee of the ACP(b), All-Union Communist Party of the Bolsheviks. An underlined dedication to the Communist Party, the choice of specific profession of "political propagandist in science" and extraordinary abilities were key to Rosenberg's survival and successful career in the Soviet society. However, because of the formation of a new ideological paradigm based on antisemitism in the Soviet Union in 19481953 Rosenberg was unable to publish his new book and lost his job at the MEL Institute. In 1950 the seventy-year-old expert on Marxism-Leninism could not bear a new round of struggle for survival and social status. The author of the article concluded, that a successful individual mobility during the revolutionary age is of particular interest. It highlights an emergence of the higher levels of the new social hierarchy on the ruins of the old society. During wars, revolutions and radical transformations in Russia in the first half of the XX century this process was extremely controversial and rapid.

\section{REFERENCES}

1. Kolesov, V.P. (ed.) (2004) Entsiklopediya Moskovskogo universiteta. Ekonomicheskiy fakul'tet [Encyclopedia of Moscow University. Faculty of Economics]. Moscow: Moscow State University

2. Sludkovskaya, M.A. (2011) Rozenberg David Iokhelevich [Rosenberg David Iohelevich]. In: Luzhkov, Yu.M. (ed.) Moskovskaya entsiklopediya. Litsa Moskvy [The Moscow Encyclopedia. Moscow Faces]. Disk 3: N-R. Moscow: Moskvovedenie.

3. The Russian Academy of Science Archives. (n.d.) Rozenberg David Iokhelevich [Rosenberg David Iohelevich]. [Online] Available from: http://isaran.ru/?q=ru/person\&guid=83E1AFD6-5E32-A327-14C7-7E4527329A5D.

4. Nam, I.V. (1982) Sibirskie organizatsii Bunda v Sibiri v 1917 godu [Siberian Bund organization in Siberia in 1917]. In: Razgon, I.M. (ed.) Voprosy istorii obshchestvenno-politicheskoy zhizni Sibiri perioda Oktyabrya i grazhdanskoy voyny [Questions of history of social and political life of Siberia between October and the Civil War]. Tomsk: Tomsk State University.

5. Nam, I.V. \& Naumova, N.I. (2003) Evreyskaya diaspora v Sibiri v usloviyakh smeny politicheskikh rezhimov (mart 1917 - fevral' 1920 gg.) [The Jewish diaspora in Siberia in terms of political regime change (March 1917 - February 1920)]. Krasnoyarsk: Klaretianum.

6. Shishkin, V.I. (2013) Sibirskiy predparlament: Chastnye soveshchaniya chlenov Vremennoy Sibirskoy oblastnoy dumy (iyun' - avgust 1918 g.) [Siberian Pre-parliament: Private meeting of the members of the Provisional Siberian Regional Duma (June - August 1918)]. Novosibirsk: Parallel'.

7. The State Archives of the Russian Federation (GARF). Fund R-7668. List 1. File 2653.

8. Sibirskiy vestnik Bunda (Tomsk).

9. Izvestiya Soveta soldatskikh deputatov Tomskogo garnizona.

10. Znamya revolyutsii (Tomsk).

11. Adrianov. A.V. (1919) Periodicheskaya pechat'v Sibiri. S ukazatelem izdaniy v $1918 \mathrm{~g}$. [Periodical Press in Siberia. With the index of publications in 1918]. Tomsk: [s.n.].

12. Sibirskaya zhizn' (Tomsk).

13. Golos svobody (Tomsk).

14. Put' naroda (Tomsk).

15. Larkov, N.S. (1995) Nachalo grazhdanskoy voyny v Sibiri. Armiya i bor'ba za vlast' [The beginning of the Civil War in Siberia. The army and the struggle for power]. Tomsk: Tomsk State University.

16. Zarya (Tomsk).

17. Golos Sibiri (Tomsk).

18. Narodnaya gazeta (Tomsk)

19. The State Archives of Tomsk Region (GATO). Fund R-1. List 1. File 38. 
20. Larkov, N.S. (2011) The Events of December 1919 in Tomsk. Vestnik Tomskogo gosudarstvennogo universiteta. Istoriya - Tomsk State University Journal of History. 3(15). pp. 46-56. (In Russian).

21. Kostyrchenko, G.V. (2001) Taynaya politika Stalina: vlast' i antisemitizm [Stalin's Secret Policy: Power and anti-Semitism]. Moscow: Mezhdunarodnye otnosheniya.

22. The State Archives of Novosibirsk Region (GANO). Fund P-1. List 1. File 86

23. The State Archives of Novosibirsk Region (GANO). Fund P-1. List 3. File 2.

24. The State Archives of Novosibirsk Region (GANO). Fund P-1. List 3. File 3.

25. The State Archives of Novosibirsk Region (GANO). Fund P-1. List 3. File 18.

26. The State Archives of Novosibirsk Region (GANO). Fund P-1. List 1. File 954.

27. Rabochiy put' (Omsk).

28 The State Archives of the Russian Federation (GARF). Fund R-4737. List 2. File 1912.

29. Rozenberg, D.I. (1929) Proizvoditel'nye sily i proizvodstvennye otnosheniya v marksistskoy politicheskoy ekonomicheskoy nauke [The productive forces and relations of production in the Marxist political economics]. Problemy ekonomiki. 7/8. pp. 136-142.

30. The Russian State Archives of Socio-Political History. Fund 588. List 3. Files 301, 302, 303.

31. The Archives of the Russian Academy of Sciences (ARAN). Fund 350. List 3. File 136

32. The Archives of the Russian Academy of Sciences (ARAN). Fund 644. List 1. File 39.

33. Khlevnyuk, O.V. (2013) Stalin. Zhizn' odnogo vozhdya [Stalin. The life of a leader]. Moscow: Corpus.

34. Galkin, D.S. (2015) V teni stalinskikh vysotok. Ispoved' arkhitektora [In the shadow of Stalin's skyscrapers. Confessions of an architect]. Moscow: Litres. 